\title{
Desberdintasuna, pobrezia eta gizarte- bazterketa Nafarroan. Krisiaren eragina 2007-2011 epean
}

\section{Ruben Lasheras Ruiz}

Nafarroako Unibertsitate Publikoa

<ruben.lasheras@unavarra.es>

\section{Izaskun Andueza Imirizaldu}

Nafarroako Unibertsitate Publikoa
Nafarroako Unibertsitate Publikoko

Berdintasunerako eta Gizarte Integraziorako Ikerketa Zentroak (BEGIZ-CIPARAIIS) kaleratu du Desberdintasuna, pobrezia eta gizarte-bazterketari buruzko lehenengo txostena, eta bertan jasotzen dira krisiak Nafarroako biztanle-gune ahulenengan izan dituen eragin nagusiak. Helburu horretatik abiatuta zehatz-mehatz aztertzen dituzte, besteak beste, lan-merkatuan gertatutako aldaketak; migrazio-fluxuen bilakaera; gizon eta emakumeen arteko desberdintasunak; pobrezia- eta bazterketaegoeren emendioa; gizarte-ekimeneko erakundeek erantzundako eskariaren hazkundea; eta prozesu horiek guztiek eragindako bizi-kalitatearen hondatze garbia. Hemen aurkeztutako dokumentuak biltzen ditu txosten horren emaitza eta ekintza-proposamen nagusiak.

\section{HITZ-GAKOAK:}

Krisia, desberdintasuna, pobrezia, gizartebazterketa, Nafarroa.
El primer informe sobre desigualdad, pobreza y exclusión social en Navarra, elaborado por el Centro de Investigación para la Igualdad y la Integración Social (CIPARAIIS) de la Universidad Pública de Navarra, exhibe los principales impactos de la crisis en la población más vulnerable de Navarra. Con este propósito, son detalladamente analizadas las transformaciones acaecidas en el mercado laboral, la evolución de los flujos migratorios, las desigualdades entre hombres y mujeres, el incremento de las realidades de pobreza y exclusión, el crecimiento de la demanda atendida por las entidades sociales y, como resultado de todos estos procesos, el nítido deterioro de las condiciones de vida. El siguiente documento traslada algunos de los principales resultados de este informe acompañados de las recomendaciones para la acción.

\section{PALABRAS CLAVE:}

Crisis, desigualdad, pobreza, exclusión social, Navarra. 


\section{Sarrera}

Berdintasunerako eta Gizarteratzeko Ikerketa Zentroa osatzen dute (BEGIZ-CIPARAIIS) Nafarroako Unibertsitate Publikoak bultzatutako erakundea da, eta gizarte-ekintza eta unibertsitate-eremuan dabiltzan hainbat erakundeek, hala nola: Iruña-Tutera Elizbarrutiko Caritas, Nafarroako Gurutze Gorria, Gaztelan Fundazioa, Ilundain Haritz Berri Fundazioa, Gizartebazterkeriaren eta pobreziaren kontrako Nafarroako sarea, ALTER ikerketa-taldea eta Hiritartasunari, Bizikidetzari eta Aniztasunari buruzko UNESCO Katedra.

Zentro honen sorkuntza loturik dago hainbat gizartegaien inguruan ikerketak egiteko premiari. Orain artean landutako gai nagusienak izan dira Gizartearen baitako desberdintasunak (generoari lotutakoak, bereziki), pobrezia, gizarte-bazterketa eta integrazioa, etnien arteko harremanak eta beste gai batzuek. Eta xede horrek bildu ditu diziplina eta ikerketa arlo ezberdinetatik etorritako ikerlariak, Gizarte Lana, Gizarte Politika, Soziologia, Ekonomia, Antropologia eta Generoaren ikasketetan adituak, besteak beste.

Ikerketa-zentro honek bere sorreratik hartu zuen ikerketa-lanen emaitzak nafar gizarteari helarazteko konpromisoa, modu honetan gizarte-eztabaidan eta gizarte- politiken diseinu eta abiaraztean benetan eragiteko asmoz; azken batean, gizarte berdinago eta bateratuagoa lortzeko xedea bilatuz. Hau da, zentroak eraiki nahi izan du errealitatearen behaketarako sistema bat, aldian behin, gure erkidegoan desberdintasun-egoeren bilakaeraren berri emateko eta haien larritasuna iritzi publikoan salatzeko helburuari segituz.

Helburu horiek guztiak aintzat hartuta, funtsezkoa da, bi arrazoi nagusirengatik, gizarte-ehunak parte hartzea zentroan. Lehenik eta behin, gizarte-erakundeek talde ahulenekin duten eguneroko hartu-emanean, testuinguru ezberdinetan ematen diren arazo nagusiak ezagutzen dituztelako. Beraz, gizarte-ikerketa aplikatuan aukera-sorta zabala eskaintzen du erakunde horiekin elkarlanean aritzeak. Bigarrenik, ikerketen emaitzak errealitate zehatzetara zabaltzeko erakunde horiek egoki-egokiak direlakoan gaude, eta era honetan, eraiki nahi izan dugu zentro honetan gure gizarteko garapena eta berdintasun- eta integrazio-mailen hobekuntza elkarrekin sustatzeko modua.

Zentroaren sorkuntzak, 2010. urte bukaeran, krisi ekonomiko latzaren testuinguruan kokaturik, bere abiaraztearen atzean zegoen kezketako bat islatzen du: krisiaren eraginez gizarteak pairatutako ondorioen gaineko aldian behingo informazioa izateko beharra.

\section{Lehendabiziko produktua: Nafarroako desberdintasun, pobrezia eta gizarte- bazterketari buruzko lehen txostena}

Ikerketa Zentroko lehenengo argitalpena izan da Nafarroako Desberdintasun, Pobrezia eta Gizarte
Bazterketari buruzko Lehen Txostena, Krisiaren eragina 2007-2011 epean. Dokumentuak erabiltzen du informazio-bilketa dinamiko bat, eta hainbat teknika ezberdin uztartuz jaio da gizartearen baitako desberdintasunak ezagutzera emateko asmoz. Lehenengo txosten honetan sakontzen da 2007 eta 2011 bitarteko epean krisiak izandako eraginean. Helburu horri jarraituz, lau ataletan banatzen da txostena.

Lehenengoak jartzen du arreta krisialdi ekonomikoak Nafarroako egituretan sortarazi dituen eraldaketetan. Norabide honetan, lan-merkatua aztertzen da, desberdintasun- eragile nagusi moduan, eta horrek langabeziaren, kontratazioaren eta talde kaltetuenen bilakaeran izandako eraginean sakonduz. Krisiaren eraginez kaltetuen suertatu direnen artean, ikertzen dira migrazioen bilakaera eta genero-desberdintasunaren alorrak.

Txostenaren bigarren atalean, ematen zaie arreta Nafarroako biztanle ahulenei, krisian zehar horiek jasan izandako bilakaerari. Horretarako, lehenik eta behin, adierazle pare bat erabiltzen dira, hala nola, Biztanleria Aktiboaren Inkesta (BAI) eta Bizi Baldintzen gaineko Inkesta. Biek ere, ahalbidetzen dute langabezian daudenen egoera latzenak identifikatzea (etxeko kide aktibo guztiak langabezian dauden kasuak, familiako pertsona nagusia langabezian daudeneko etxeak, diru-sarrerarik gabeko etxeak, etab.). Bigarrenik, aztertzen da lehen-mailako beharrak asetzera zuzendutako gizarte-ekimeneko erakundeek jasandako eskaera, erakundeen beraien datu-baseetatik abiatuta. Eskaera hori hartzen da beste adierazle gisa, eta, batetik, laguntzen du erakundeek burututako esku hartzeen bilakaera ezagutzen; eta, bestetik, ahalbidetzen du artatutako pertsonen gizarte- eta demografia-ezaugarrien aldaketak aztertzea.

Txostenaren hirugarren atalak erabiltzen du ikuspegi metodologiko kualitatibo bat, hogeita hamalau kasuren bizi-baldintzen azterketatik abiatuta, Nafarroako sektore ahulenen eguneroko errealitatera hurbilduz. Biografian oinarritutako ikerketateknika horrek ahalbidetzen du oztopoen metatzea, laguntzen galtzea eta beheranzko ibilbideak identifikatzea.

Azkenik, emaitza eta ondorio nagusiak biltzen ditu dokumentuak bere azken atalean. Zentroa osatzen duten erakundeen jarrera hartzearekin bukatzen da ariketa hau, administrazio publikoei gizartekohesioa mantentzeko eta haustura soziala saihesteko iradokizun-multzo bat helaraziz.

Eskuartean duzun testu honek helburu du BEGIZ ikerketa-zentroak Nafarroako lurraldean desberdintasunen harira egindako lehenengo gerturatze-saio horretatik ateratako emaitza eta ondorio nagusiak zabaltzea. Horretarako, azalpen metodologikoa erabiliko dugu, txostenaren filosofia bera erabiliz, deskribapen-dimentsioa eta proposizio-izaera uztartuz. 


\section{Krisiaren eragina gizartean: Nafarroako errealitateari lehengo hurreratze bat}

Eragin bortitza izan du finantza-arlotik abiarazitako krisi ekonomiko gogorrak espainiar lurraldeko ekonomian, besteak beste, bere ekoizpen-sarearen eta bere lan-merkatuaren ezaugarriengatik; eta baita ere azken urteetan garatutako eraikuntza espekulazioprozesuagatik. Krisiaren larritasun berak sortarazi ditu eztabaida sakonak, arlo akademiko eta politikoak gainditu eta gizartean barrena zabalduz, krisia pairatzen duen subjektu nagusia den horretan zehar, hain zuzen.

Nafarroak krisia piztu aurretik zuen kohesio-mailari esker, hobe jasan ahal izan ditu krisiaren ondorioak. Estatuan ematen den ekoizpen-sarea baino kualifikatuagoa eta desberdinagoa izateak laguntzen du ulertzen Nafarroan Estatuarekin alderatuz enpleguaren suntsitze motelagoa gertatu izana. Gizarte-ehuna familia-sare sendoz osaturik egoteak, diru-sarrerak eta zaintzak birbanatzeko gaitasuna izateak, batik bat, nolabait saihestu izan du langabezian dauden pertsonak edota errealitate larriak bizi dituzten horiek erabat babesik gabe geratzea. Azkenik, arindu egin dute gizarte-zerbitzu publiko eta gizarte-ekimeneko erakundeen jarduerek krisiak Nafarroako sektore ahulenengan izandako lehenengo inpaktua, hasieran behintzat. Nolanahi ere, ez du inolaz ere estali behar, nolabaiteko abantaila konparatibo horrek (krisiaren hasierako fasean gertatutakoak, batez ere), krisiak gizarte-mailan izan duen eragin larria.

Iturri ezberdinen azterketek agerian uzten dute krisiak modu negatiboan nola eragin dien gizarteko talde ahulenei, eta prozesu horrek nola jartzen duen kohesio soziala kolokan.

Enplegua, gizarte-babesa, aukera-berdintasuna edo etorkinen gizarteratzea dira nabarmenki kaltetutakoak. Atzerakada horiek inpaktu zuzena dute bizi-baldintzen eremuan, bereziki edozein babes sozialetik kanpo geratzen diren pertsonen kasuan. Arazo horien larritasunak Estatuko ongizateereduarekin alderatu izan den Nafarroako ongizateereduaren porrota agerian uzten dute maiz. Lehenago esan bezala, paradoxikoa ematen badu ere, langabezia edota pobrezia erlatiboko tasa baxuagoak izatean oinarritzen zen izaera bereziko gizarteongizate bat izateak, gaur egun ematen diren egoera larriak politikoki eta gizarte-mailan ukatu eta aintzat ez hartzera eraman dezake.

Hemen aurkezten den ikerketaren ondorio nagusietako bat da, hain zuzen, krisiak Nafarroako gizartean izandako eraginaren inguruan informazio eta eztabaida publikoaren hutsunea. Adierazle ekonomikoetatik eratorritako informazio-bolumen ugariaren aldean (barne-produktu gordina -BPG-, defizitmaila, etab.), ez da modu sistematikoan sakontzen langabeziak, diru-sarrerarik gabeko etxeen errealitateak edota baztertutako pertsonen egoerek gizartean izaten duten eragina. Gabezia hori, Nafarroan etxe ahulenetako bizi-baldintzak ezagutzeko kalitatezko informazio-iturri urritasunaren ondorio da, nagusiki. Hala ere, informazio-eskasia dago gizartezerbitzuetara jotzen duten pertsonen inguruan ere; haien arazoen inguruan; sare horrek eta bere prestazioek erantzuteko duen gaitasunaren inguruan; edota pobrezia eta gizarte-bazterketa egoeran dauden pertsonek osatzen duten eskari potentzialari dagokionaren inguruan ere.

Egoera horren aurrean, esan genezake hainbat jarduera politiko inprobisatu izan direla (Gizarteratze Errenta bihurtu izana Oinarrizko Errenta edota gizarteeta lan-programen murrizteak, esaterako), ez baitzuten kaleratu neurri horiek gizartean izango zituzten ondorioen inguruko txostenik. Gaur egun pairatzen ari garen krisi honek eskatzen du informazio-bilketarako mekanismo zorrotzak izatea eta datu horiek jendartera zabaltzea. Izan ere, modu bakarra izango baita gaur egungo zailtasun-egoera honi erantzungo dieten eredu ekonomiko eta sozialen inguruan dauden eztabaida eta erabaki hartzeak gidatzeko.

\section{Krisia eta lan-merkatua: langabezia, ezegonkortasuna eta talderik ahulenak}

Aztertutako epean (2007-2011), langabeziaren emendio azkarra izan da Nafarroako lan-merkatuaren ezaugarri nagusia. Nahiz eta langabezia oso hedatua egon, datuek agerian uzten dute horrek ohiko talde ahulenei eta lehendik baldintza okerrenak pairatzen zituztenei gehiago eragiten diela. Azken horiek dira, hain zuzen, krisiak gogorren astindu dituenak, besteak beste, gazte, etorkin eta 45 urtetik gorako pertsonak. Gainera, maila handiagoan eragin die gizonezkoek presentzia handiago duten produkziosektoreei. Eraikuntzaren sektorea da horren adibide esanguratsuena. Sektore horrek hasieran krisiaren eraso gogorrenak bildu zituen (eta biltzen ditu oraindik ere), aldi baterako enpleguen suntsipen handia zela-eta. Bereziki larria da, halaber, krisiak industriasektorean utzitako arrastoa, sektore horrek biltzen dituen balio handiko jarduerak pilatzen dituelarik eta sektoreak berritzeko duen ahalmen eskasagoa kontutan harturik. Era berean, enplegu-kopuru handia galdu du zerbitzu-sektoreak, merkataritza eta ostalaritzan, batik bat. Horri guztiari gehitu behar zaizkio gaur egun sektore publikoan ematen ari diren murrizketak. Testuinguru honetan kontratazio mugagabea ez da euskarri askia izan kaleratzeen aurrean. Horrenbestez, langabezia-maila oso altu mantendu izan da krisia hasi zenetik.

Estatua bere osotasunean hartuta baino, frogatu da krisiaren ondorioak Nafarroara beranduago heldu zirela, bai eta krisiaren adierazpide batzuk gurean modu apalagoan agertu zaizkigula ere. Errealitate honek agerian dagoen larritasuna estali behar ez badu ere, argi asko antzematen da hori lan-eremuan. Ikasketa-maila altuagoa, balio erantsi handiagoa duten jardunen presentzia, ezkutuko lanen portzentaje baxuagoa edota kalifikazio altuagoko okupazioak dira, besteak beste, krisiaren eragina ahulagoa izatea ahalbidetu duten bereizgarriak. Norabide berean, 
beste faktore erabakigarria izan da industriak ekonomian duen pisua. Aipatutako langabeziaren eraginaz gain, oraindik ere Nafarroako okupazioan industriasektoreak garrantzi handiagoa izaten jarraitzen du zerbitzu-sektoreak baino, eta azkeneko hori dago krisiak gehien astindutakoen artean.

Arestian aipatutako langabezi errealitate historiko eta kezkagarri horretatik baino haratago, asaldagarria da sektore estrategikoetan galdutako enpleguak ikustea, bai eta sortu diren enplegu berriak zein eskasak diren ikustea ere, bereziki lan-merkatutik kanpo denbora luzez egon direnek pilatutako ahultasunari aurre egitean. Esan bezala, langabeziak Nafarroan, okupazio-mailan gertatzen den bezalaxe, neurri handiago batean eragin die lan-merkatuan denbora gutxiago daramaten pertsona eta kalitate okerragoko kontratuak dituztenei. Gaur egun lan-merkatutik kanpo kopuru altuan geratu dira gazte-talde ( 25 urtetik beherakoak), zahar (45 urtetik gorakoak), atzerritar eta, bereziki, ikasketa-maila baxuenekoak. Lehenengo bi taldeei dagokionez, zailtasunak agerian geratu dira aldi baterako kontratuak izanik lan-merkatutik kanpo geratu diren pertsonei eta sekula lanik egin ez dutenei zuzendutako enpleguaukera berriak sortzeko. Heziketa- edo prestakuntzamaila baxua dutenei erreparatuz, eta alderdi hori lan-merkatuan sartzeko erabakigarria izanik, egoera hoberenean jarrita ere, pentsatzekoa da enpleguak sortuz gero, lanpostu berriak prestakuntza-maila baxuena dutenek baino kalifikazio-maila altuagoko langabetuek hartuko lituzketela lehenago. Azken hauek langabezi ibilbide motzagoak dituzte, eta enplegugarritasun-maila handiagoa dute adina, nazionalitate eta familia-kargei dagokienez.

Azken alderdi horri helduta, esan dezakegu prestakuntza-maila altuagoa izateak langabezi gutxiago izaten lagundu duela, alabaina, horrek ez du eragotzi lanpostu kualifikatu kopuru esanguratsu baten suntsitzea. Modu berean, prestakuntza eta langabeziaren arteko korrelazioak (gero eta prestakuntza handiagoa izatean, orduan eta langabezi gutxiago izateak) ez du ekarri prestatutako pertsonek lan-merkatuan beren mailako lanpostuen eskaria proportzio berean sortzeko gaitasunik. Aitzitik, horrek eskatzen du produkzio-sistemaren berrantolaketa bat, eskaria eta eskaintzaren arteko egokitasun handiagoa eman dadin eta dagoen prestakuntzaren klasegabetze larria arintzearren, hau da, ikasketamaila eta lanpostuen kualifikazio-mailaren artean ematen ari den desoreka kezkagarria arindu dadin. Horretaz gain, ezin ahaztu dezakegu biztanle ahulenen gehiengoa prestakuntza-eremutik at dagoela.

Egoera horien ondorio nagusiei dagokionez, lehenik eta behin esan dezakegu langabeziak diru-sarrera gabezia suposatzen duela. Halabehar horrek, eta gizarte-segurantzako sistemak babestutako arriskuen artean aurkitu arren, krisialdi aurretik ere mugak zituen aldez aurretik kotizaziorik gabeko langabetuak babesterako garaian. Hala ere, momentu honetan, esan dezakegu kotizaziopeko babesa ere kolokan dagoela. Langabezi egoera horren luzeak kontuan hartzen ez dituen sistemaren eragin eta jasan izandako hainbat erreformen ondorioengatik oso mugatuak dituen eskumen eta estaldurak direla-eta, kaltetuen izan dira, batez ere, lan-merkatuan sartzen azkenak eta baldintza okerrenetan zeudenak. Horren ondorioz, emendio nabarmena ekarri du krisiak inolako diru-sarrerarik ez duten langabetuen kopuruan. Pertsona horien artean aurkitzen ditugu, esaterako, kotizazio-ibilbide luzeak izanik, lehenik kotizaziopeko prestazioak eta ondoren diru-laguntzak ahitu dituztenak. Diru-sarrerarik gabeko pertsona-multzo honetan, aldi baterako lanak egiten ari zirenak ere badaude, eta inolako langabezia-prestaziorik ez dute izan langabezian geratzerakoan. Azkenik, azpimarratzekoa da lan-merkatuan sartzeko aukerarik izan ez dutenen kasua ere. Ikerketa hau bukatutzear zen momentuan, talde horrek, diru-sarrerarik gabeko langabetu nafarren \% 36a osatzen zuen.

Teknika kualitatiboen bidez jasotako datuek erakusten digute lan- edo prestazio-gabeziagatik diru-sarrerarik ez edukitzeak langabetuen bizi-baldintzetan ondorio negatibo multzoa ekartzen duela, adibidez: erosteko ahalmena galtzea, alokairu edota hipotekakredituei aurre egiteko zailtasunak, etxeko ohiko gastuak ordaintzeko arazoak, oinarrizko beharrak asetzeko ezintasunak (elikatzea, janztea, sendagaiak izatea, etab.), osasun-arazoak, familia- eta gizarteharremanen okertzea, etab. Kasu horietan guztietan, funtsezkoa suertatzen ari da familiak eskainitako babesa. Bizi-kontakizunek erakutsi dizkigute langabezian dauden pertsonek laguntza bilatzeko erabilitako estrategia ezberdinak, eta autonomia pertsonalaren kontrakoak dira kasu batzuetan. Esaterako, guraso edo familiakoen etxera bueltatzen diren gazteak; bereizteko prozesuan egonik etxe berean bizi diren bikoteak; gastuak murriztearren, familiakoak ez diren beste pertsonekin etxea konpartitzen duten kasuak, etab. Azken finean, langabezi egoera beste diru-sarrera edo etxeko beste kide batzuen diru-laguntzekin osatuz gero, nolabait arintzen dira ondorioak. Dena dela, etxe batean diru-sarrerarik ez duen familiako pertsona nagusia edo pertsona aktibo guztiak langabezian direnean, langabezi egoerek estualdia eta pobrezia dakarte.

Frogatu den moduan, enpleguak behera egin du, bai eta bere kalitateak ere. Krisia eta lan-ezegonkortasuna eskutik doaz. Nafarroako Gobernuko kontratazioen datu-baseak agerian uzten du aldi baterako kontratazioen emendioa eta lan-baldintzen okertze nabaria. Bestalde, ezin ahaztu daiteke ezkutuko ekonomia eta irregulartasuna mantentzen direla. Nahiz eta analisi gehienetan bi fenomeno horiek ilun izaten jarraitzen duten, gure ikerketan, erabilitako teknika kualitatiboek eta gizarte-ekimeneko erakundeek haien egunerokoan biztanle ahulenekin egindako lanean bildutako jakintzaren bidez, lortu dugu errealitate horiei buruzko informazio aberatsa jasotzea. Ezkutuko ekonomiari dagokionez, lan-aukera eta babes-mekanismo gabeziek eragiten dituzte halako ezkutuko jardunetan aritzea diru-sarrerak lortzeko (etxeko lan, eta 'lantxoen' moduan, esaterako). Egoera horietan agertzen dira ordutegi, soldata eta lan-baldintzei lotutako lan- 
esplotazio adibideak. Joera horiek, enplegu krisialdi ezberdinetan historikoki frogatu izan den moduan, arriskua dago gaur egun areagotzeko, azkenaldian izan den lan-erreforma dela-eta.

Testuinguru honetan zer egin beharko litzateke? Nafarroan enplegua sortu eta mantentzea da erronka nagusia, eta horrek, aldi berean, eskatzen du lortu nahi den produkzio-ehuna adostea. Baina epe motzean abian jartzeko ekintza zehatzei erreparatuta, adostu beharko litzateke lortu nahi den produkzio-ehuna. Baina epe motzean abian jartzeko ekintza zehatzei dagokionez, lehenik eta behin, ezinbestekoa da langabeziari zuzendutako eskaintza handitzea. Prestakuntza eta enplegugarritasunaren arteko lotura kontuan hartuz, premiazkoa da kualifikatu gabeko langabetuei kontu hartzea, prestakuntza pertsona horien beharrei egokituz eta orokorrean prestakuntzari nabarmenki erreparatuz. Hau da, langabeziak gazte eta luzaroko langabetuei bezalako talde ahulei eragin dienez, hartuko diren neurriak arrakastatsu gertatzeko, alde formalak egokitu (edukiak, ordutegiak, etab.) eta bereziki laguntza ekonomiko eta sozialak jaso beharko lituzkete. Zentzu honetan, beharrezkoa da prestakuntzako katalogoa eguneratzea etengabe aldatzen ari den eta prestatuen daudenei ere aukera gutxi eskaintzen dien lan-merkatura egokituz. Hori dela-eta, prestakuntza-eskaintza, aldez aurretik duden lan-aukeren azterketan oinarritu beharko litzake eta alderdi praktikoari garrantzia eman, eskaintza eraginkorra izan dadin langabetuak lan-munduan txertatzerakoan.

Gazteak eta zailtasun bereziak dituzten luzaroko langabetuen inguruan egindako lanek erakusten dute kualifikazio-praktikak egokiak direla aldez aurretik enplegu babestutako lan-aukerak diseinatzean kontuan hartzeko. Hori enplegu-sorkuntzako programen bidez lortzen da, eta zentzu horretan oso egokiak suertatzen dira gizarteratze- eta laneratze-zentroak, kontratuetan hainbat klausula sozial dituzten gizarteizaerako enpresak, administrazioetan lanerako zailtasun bereziak dituzten pertsonak kontratatzea, etab.

Azkenik, helduko diogu garrantzi gutxiagoa ez duen kontu bati, lanetako onartze-atarien mailari. Hori maila kezkagarrietara iristen ari dela antzemanda, eskatu behar da diru-sarrerarik gabeko babes ekonomikoa, esplotazio-egoera hori jasaten dutenen gizarteratzeko tresna moduan ez ezik, ezegonkortasuna eragiten duten praktiken gehiegizko hedatzearen aurrean, gizartearen osotasuna defendatzen duen formula gisa.

\section{Krisia eta generoa: gizon eta emakumezkoen arteko berdintasunerako oztopoa}

Generoen arteko desberdintasunek, krisiaren aurrekoek ere, krisiaren inpaktua baldintzatu dute hein handi batean, noski. Emakumeek lan-merkatuan sartzeko jasaten duten segmentazioa, nabarmenki egin dute gora hirugarren sektorera jotzea edota etxeko lan eta arreten banatze desorekatua bezalako fenomenoek, gizarte berdinago bat izateko desioen kontrakoak izan arren. Nahiz eta krisiak hasieran irakurketa maskulino bat izan (gizonezkoen egoerak nabarmenki okertu baitira), emakumezkoen egoerak, hobera ez egiteaz gain, errealitate oso kezkagarriak erakusten ditu. Adibidez, egiaztatu da pertsona nagusia emakume bat den etxeetako egoera gizonezko batena baino okerragoa dela. Hori gertatzen da, neurri handi batean, emakumeek lan-merkatuan sartzeko dituzten oztopoengatik eta diru-sarrerak galtzean pairatzen duten ahultasun berezia dela-eta. Horregatik, pobrezia-datuetan agertzen dira maiz emakumezkoak buru diren etxeak. Esaterako, Nafarroan, dirusarrerarik gabe bizi diren etxeen erdia baino gehiagotan emakumezkoak dituzte buru, hain zuzen.

Langabeziari dagokionez, krisiaren eragina lanmerkatuan ezaugarritzen den errealitatea den heinean, gainetik dago emakumezkoen langabezia-tasa gizonezkoen aldean. Europar Batasunetik kanpoko emakume etorkinak eta emakume gazteak dira kaltetuenak. Gainera, emakumeak denbora luzeagoz izaten dira egoera horretan, eta diru-laguntza gutxiago jasotzen dute (langabezian dauden gizonen \% 43ak diru-laguntzaren bat jasotzen duten bitartean, langabetu emakumeen $\% 27,1 \mathrm{k}$ baino ez du hori lortzen). Horretaz gain, ezin ahaztu dezakegu emakumezkoen langabezia gizonezkoena baino okerrago dagoela babestua, emakumezkoen lan-historietan errealitate ezegonkor gehiago pilatu ohi direlako (lanen aldi baterakotasuna, lanaldi partzialeko jardunak, etab.). Errealitate ezegonkor horiek baldintzatzen dute gizarte-segurantzako prestazioak lortzea, kotizaziopekoak baitira, eta gizonezkoen lan-ereduan oinarriturik baitaude.

Lan-merkatuaren beste alderdi batzuei helduta, emakumezkoen jarduera-tasak gora egin du 2007 eta 2011 bitartean. Ordaindutako lan-merkatuan lanean hasitakoen artean, Europar Batasunetik kanpoko jatorriko emakumeen kasuak izan dira nabarienak. Tarteko adinetan igo egin da emakumeen jardueratasa (25-45 urte bitartean), 55 urte baino gehiagokoena mantendu da, eta gutxitu egin da gazteenen artean. Hori azpimarratzeko moduko gertaera da, aurreko krisialdi batzuetan emakumezkoak etxera bueltatzen zirelako. Beraz, gaur egun, bat egiten dute emakumeen lan-merkatuan jarraitzeko asmoek batetik, eta gizonezkoen lana galtzearen ondorioz sortutako zailtasun ekonomikoek, bestetik (familiaekonomia egoerari egokitzea).

Arlo honetan, genero-irakurketa batetik abiatuta, 'beheranzko berdintzea' da aurkitzen dugun fenomeno esanguratsuenetako bat. Gertaera hori ematen da bi norabidetan. Lehenik eta behin, 1,4 puntu egin du gora emakumezkoen jarduera-tasak, gizonezkoenak berriz, 10 puntu behera. Krisiaren lehenengo faseetan langabeziaren emendioak gizon eta emakumeen jarduera-tasak 11,4 puntu gerturatu dira, nahiz eta oraindik ere emakumezkoenak gizonezkoenak baino 10 puntu gorago dauden. Adinari dagokionez, bereziki agerikoa da 'beheranzko berdintzea' 25 
urtetik beherakoengan, berdintze hori ezegonkortasun eta lana aurkitu eta mantentzean berresten delarik. Prestakuntzari erreparatuz gero, antzematen da genero-arrailak bi joera nagusi marrazten dituela. Alde batetik, prestakuntza handieneko pertsonen jarduera-tasaren jaitsiera, gizonezkoen jardueratasak prestakuntza-maila guztietan behera egin eta goi-mailako ikasketak dituzten emakumezkoen jarduera-tasaren gorakada gertatu delako. Bestetik, emakumezkoen artean behera egin dute prestakuntza-maila baxuenen jarduera-tasek. Emakume horiek prestakuntza-maila bera duten gizonezkoek baino zailtasun handiagoa dute lana aurkitzerakoan.

Lan-baldintzei erreparatuz gero, emakumezkoen lanak ordainsari txikiago, aldi baterakotasun handiagoa eta lanaldi partzialeko lan-tasa altuagoak izaten ditu. Soldatei dagokionez, gizonezko eta emakumezkoen arteko soldata-desberdintasuna murriztea lortu du enpleguaren ezegonkortasunak. 2009ko datuen arabera, generoen arteko soldaten ezberdintasuna \% 21,5ekoa zen (Estatuko okerrena). Kopuru hori 2007-2009 urteen artean gutxitu zen, maila baxueneko lanbideetan desberdintasunak murriztearen ondorioz, baina prestakuntza-maila altu eta erdikoetan berriz, hazi egiten da desberdintasuna. Lanaldi partzialeko lanei dagokionez (emakumezkoen enpleguak dira horietatik \% 82,5), nahigabeko egoerak dira kasu gehienetan: lan-merkatuak jardunaldi osoei jarritako betoaren ondorio dira, edota familiakoen zainketen ardura beregain hartu izan eta lanarekin bateratu ahal izatearen ondorio (haurrak, mendekoak, etab.).

Emakumezkoak ordaindutako lanetan hasi izanagatik ez da ugalketa-aferei eta bizitzaren mantentzeari eskainitako astia banatu (etxeko lan eta zaintzak batik bat). Adierazleek erakusten dute zeregin horiekiko erantzunkidetasun ezberdinak dituztela. Emakumezkoek gizonezkoek baino ordu eta erdi gehiago eskaintzen diote egunero etxe eta familiari. Ordaindutako enplegua duten emakumezkoek ere ez dute lortu etxeko lanei eskainitako denbora jaistea azkeneko zazpi urteetan, beraz, lan-zama astunagoa jasaten dute orokorrean. Amatasun eta zaintzak orokorrean emakumezkoek bakarka hartzen dituzte beregain hamabost urte beherako adingabekoak dituzten etxeen kasuen erdian ia-ia (\% 41n), nahiz eta haien \% 70ak ordaindutako lana izan etxetik kanpo. Desgaitasunen bat duen pertsonak tartean direnean, areagotzen dira zainketen desberdintasun horiek. Eginkizun horiek emakumezkoek beregain hartzen dituzte \% 82ko portzentajean.

Familia-babesera jo izan da krisiaren ondorioei aurre egiteko estrategia gisa, eta horrek etxeko lanen areagotzea ekarri du eta ikerketa honetan egiaztatu ahal izan denez, zama hori emakumezkoek hartu dute neurri handi batean. Modu berean, murriztu dira etxeetara diru-sarrera urriagoak sartzean etxeko lanak egiteko edo zainketetarako kontratatutako zerbitzuak ere, lan hori familiak berak beregain hartuz (berriro ere emakumezkoek neurri handiago batean). Asko baldintzatzen dute egoera horiek emakumeen laneratzea.
Krisia mantentzea zerbitzuetako enpleguen suntsipena ekartzen ari da alde batetik; eta bestetik, mantendu diren enpleguen ezegonkortasuna. Bi gertaera hauek emakumezkoei zuzen-zuzenean eragiten diete. Adibidez, 2011.urtean, etxeko langileen araubidean Gizarte Segurantzan afiliatutako \% 95,7 emakumeak dira, eta atzerriko jatorria dute haietako bi herenek. Azken urte honetan sektore honek nabarmenki gora eginagatik, etorkizunean beherakada handi bat jasan lezake bi fenomeno nagusi direla medio. Batetik, murrizketen ondorioz mendekotasunerako laguntzak urritu direlako; eta bestetik, etxeetara sartzen diren irabaziak gutxitzean zerbitzu horiek ere gutxiago kontratatzea dakarrelako. Europatik kanpoko jatorriko emakumeak dira lanpostu hauen galtzea gehien jasaten ari direnak, eta historikoki sektore horretan eman den ezegonkortasuna areagotzen ari da haien arteko konpetentzia dela-eta. Adibidez, ezegonkortasuna areagotzeko arriskua handitzen du etxe batean lanean ari den pertsona etxe horretatik kanpo bizitzetik bertan bizitzera pasatzeak. Hala nola, etxeetan diru-sarreren urritzearen ondorioz, datozen gastuen murrizpenetan oinarritutako estrategiek ekarri ohi dute bertan lan egiten dutenen lan-baldintzen okertzea: soldata txikiagotzeak, denbora gutxiagotan lan gehiago egin behar izatea, etab.

\section{Etxeko langileen inguruko lege berriak eragingo} dituen ondorioak baloratzea zaila suertatzen bada ere, ematen du horrek hobekuntza batzuk ekarriko dituela. Hala ere, lege honek ez du lortu lanbide horretan ari direnak beste lan-erregimenetan dabiltzanen eskubideekin parekatzea. Modu berean, pentsatzekoa da murrizketa sozialek tradizionalki zerbitzuei lotutako enpleguei eragiteaz gain (merkataritza, ostalaritza, etxeko lan eta zaintzak, etab.), emakumezkoak protagonista diren beste jardunei ere biziki eragingo dietela, adibidez, hezkuntza, osasuna, gizarte-zerbitzuak, kultura-jarduerak, gobernuz kanpoko erakundeek abiarazitako jardunak, eta hirugarren sektorea deritzonari, besteak beste. Azken finean, murrizketaegoera honek dakar aurreikusi gabeko eta desiratzen ez zen ondorio bikoitz bat. Alde batetik, lan-aukera murrizketa nabaria ematen ari da tradizionalki emakumezkoak aritutako sektoreetan. Bestetik, gertatzen ari da gizarteak bere osotasunean duen ongizatearen galtze progresiboa, etxe ahulenetan zerbitzu horien gabeziak bereziki eragiten duelarik.

Emakumezkoei zuzenean eragiten dieten beste gertaera edo fenomeno batzuk ematen ari dira, halaber. Ugalkortasunaren gutxitzea, esaterako, lana, familia eta bizi pertsonala hobe uztartzeko garatutako estrategia moduan identifikatu izandakoa, emakume etorkinen etorrerarekin batera murriztu izan zen azken urteotan. Gaur egun, ordea, hainbat adierazleri erreparatuz gero (jaiotze-kopurua, jaiotze-tasa gordina, etab.), agerikoa da ugalkortasuna gutxitzen ari dela. Harreman-aferei helduta, azken urteetan areagotzen ari ziren banatze prozesuak, 2008 eta 2010. urte bitartean $\% 5$ gutxitu ziren. Estrategia moduan agertzen ari da banatze-prozesuak gelditzea ekonomiazailtasunak eragozteko, nahiz eta ondorioak sortarazi afektibitate-loturetan. Banatzeak gertatzen direnean 
eta adingabeak tartean daudenean gurasobakarren etxeak sortzen dira (Nafarroako etxeen \% 5 a dira). Nafarroako kasuan, emakumeak buru dituzten lau gurasobakarreko etxeetatik hiruk arrisku-aukera handiagoa dute ahultasun, pobrezia eta gizartebazterketa pairatzeko. Arrisku horien areagotzea ematen da emakumea buru den pertsona bakarreko etxeetan $(\% 53,3)$. Etxe horiek, 65 urtetik gorako emakumeek osatzen dituzte, batez ere, erretiro-pentsiorik ez dute izaten, edota jasotzen ari dira kotizazio gabeko alargun-pentsioa. Muga ekonomiko horietaz gain, agertu ohi dira adinari lotutako arazoak.

Laburbilduz, eskubideen berdintze baten ordez, ematen ari da ezegonkortasuneranzko berdintze bat. Hau da, berdintze hori ez dator emakumeen baldintzen hobekuntzatik, baizik eta gizonezkoen egoeren okertzearen bidetik. Errealitate horri aurre egiteko beharrezkoa da krisialdi garai honetan ongizatearen babes publikoaren indartzea. Horrek, emakumezkoak buru diren etxeak baztertze-egoeran ez erortzea eragozteaz gain, emakumezkoentzako enplegua sortu eta gizarte-ongizatea sustatuko luke.

\section{Krisia eta immigrazioa: gizarteratze prozesuetan eteteak}

Gaur egungo abagunea dela-eta, gero eta etorkin kopuru txikiagoak aukeratzen du Nafarroa haien bidaien norako. Eta bertan bizi ziren etorkin batzuek alde egin dute (gutxiengoak badira ere). Azken batean, testuinguru ekonomikoaren eraginez orain Nafarroa ez da migrazio-fluxuetarako horren leku erakargarria suertatzen. Edonola ere, esanguratsua da Nafarroan bizi den jatorri atzerritarren kopurua, eta modu bortitzago batean pairatzen ari dira krisiaren ondorioak.

Azken urteetan, aurrerakada garrantzitsua antzematen zen Nafarroara goeko hamarkadatik aurrera etorritako etorkinen gizarteratzean. Hasieran, etorkinek lan-merkatuan sartzeko bizitako zailtasunei, haien administrazio-egoera legeztatzeari eta haien familiak ekartzeari lotutako arazoei aurre egin ondoren, nabariak ziren bizitako hobekuntzak bai lan arloan, administrazio egoeran bai eta gizarte partaidetzan ere. Alabaina, krisiaren eskutik etorri den enplegusuntsipenak, aldez aurretik lortutako gizarteratzemaila kolokan jarri du lan-ezegonkortasun edota dirusarreren gutxitzea bezalako fenomenoen ondorioz. Gertaera horiek etorkinei ez ezik, eragin dio gainerako nafar gizarteari ere, kohesio soziala arriskuan jartzen baitu talde horren ahultasunak.

Gauzatzen ari zen etorkinen gizarteratze-ereduak, aipatutako lorpenaz gain, agerian uzten zuen haustura-arrisku hori. Alde batetik, lan-merkatuaren beharrei baldintzatuta egon izan da pertsonen egoera administratiboaren arautzea, eta behar horiek kokatu izan dira ezegonkortasun handia erakutsi duten sektore horietan, besteak beste, eraikuntzan, nekazaritzako elikagaien industrian edo zerbitzuetan (aldi baterakotasun eta ezegonkortasun handia izanik kasu batzuetan). Horren ondorioz, etorkinen kasuan eskubideen aitortzea lanari lotuta dagoen moduan, lana galtzeak ekartzen du diru-sarrerarik ez izatea eta egoera administratiboa arriskuan jartzea. Norabide honetan, lortutako datuetatik abiatuta, gaur egungo enplegu krisi latz honek eragin bikoitza dauka etorkinengan langabezia-tasei dagokionez (etorkinen artean $\% 30$ eta bertakoen artean \% $15 \mathrm{da}$ ). Beraz, arriskua altua da gertatzez irregularra izateko. Baina ez dugu ahaztu behar, lana galtzea ez dela oztopo bakarra. Prestakuntza-maila baxuko, hau da, ezegonkortasunarrisku areagoa dutenen lanpostuetan egiaztatu da lanean ari diren etorkin-proportzioak gora egin duela. Azken batean, pertsona etorkinek beregain hartu dute egoera honetan Nafarroako lan-merkatuaren segmentazio-maila altuak eragindako kostuen zati handi bat.

Aipatutako enplegu, egoera juridiko eta administratiboaren arteko harremanari dagokionez, ditugun datuek ez dute erakusten irregulartasun-maila igo denik. Hala ere, gaur egun, abegi-zerbitzuetan lanean diharduten gizarte-erakundeek ohartarazi dute fenomeno hori antzeman dutela. Erakunde hauek, halaber, Estatu-mailan ematen ari diren migrazioarauen aldaketek gizartean sortarazten ari diren eragin negatiboak nabarmendu nahi izan dituzte, sustraitzeari lotutako araupetzea eta familiakoak berriz elkartzeko eskubideak desagertzen direlako. Nafarroari helduta, oso kaltegarria da Oinarrizko errentatik 'Gizarteratze-errenta' izateko araudialdaketa ere, etorkinek gutxieneko diru-sarrerak izateko duten eskubidea urratzen delako. Erroldatzeibilbide luzeagoak eskatzeak, babes gabe gelditzeko arriskuan jartzen ditu inolako diru-sarrerarik ez duten etorkinen etxebizitzak.

Lehenago esan moduan, gure erkidegoko etorkin gehienek gizarteratzean izan duten garapen-mailak erakutsi du haien herrialdeetara itzultzea ez dela gehiengoarentzat aukerarik hoberena. Haien kokalekuak bertan mantentzera eramaten dituzte familia ekarri izanak, sortutako loturek, etxea erosi izanak (eta batez ere zorretan dituzten maileguek) edota haien herrialdeek pairatzen dituzten egoera latzagoek, besteak beste. Momentu honetan, egoera horrek suposatzen du krisiari bertakoek baino egoera latzagoan aurre egin behar izatea. Horretarako, informazio kualitatiboak erakusten digu, esaterako, zein nolako estrategiak garatzen ari diren, etxeetan lan gehiago eginez, ezegonkortasunaren bidez, aurreztuz, edota etxebizitzari ahalik eta etekin handiena atereaz. Azken errealitate honi begiratuz ikus dezakegu bizilekuetan pilatzea krisiari aurre egiteko estrategia gisa, ditugun datuen arabera, ez dira metatze-errealitateak sortzerainokoak izan. Baina etorkin-familia kasu askotan, tartean adingabekoak dituztelarik, aipatutako estrategi ezberdin horiek ez dira aski gizarteratzetik bazterketara doazen prozesu azkarrak eragozteko. Beheranzko prozesu horiek enplegua amaitzean hasi eta oraingo babes ekonomikoaren hutsune horrekin areagotu dira. Etxebizitza galtzea edo norberak hautematen duen osasunaren okertzea dira (fisiko edo mentala) prozesu horien ondorio larrienak. 
Laburbilduz, etorkinen ahultasuna agerikoa da. Testuinguruari dagokionez, oparoaldi-zikloa amaitzeak ekarri du aldez aurretik aldekoa ez zen egoeraren okertze nabaria. Krisialdi ekonomikoak agerian utzi du funtsean lan-merkatuan oinarritutako gizarteratze-ereduaren ahultasuna, are gehiago, etorkinak bertan modu ezegonkor batean aritu izan direnean (aldi baterako izaerako lanpostuak, kalifikazio eskasekoak, etab.). Agerikoak dira, beraz, enplegua suntsitzearen ondorioak, eta kolokan jarri ditu aldez aurretik lortutako gizarteratze-prozesuak. Horregatik, beharrezkoa da krisiaren aurretik arlo honetan erdietsitako lorpenek atzera egin ez dezaten gizarteratze-ereduaren inguruan hausnarketa sakon batetik abiatutako neurriak hartzea.

\section{Krisia eta gizarte-egitura: estutasunik gabeko klaseek osatutako gizartea, birbanatzeko gaitasun gutxiago duena eta gero eta pobrezia larriko egoera gehiago biltzen dituena}

Krisiak lan-arloan aipatu moduan eragin badu ere, Nafarroako gizarte-egituran ez da aldaketa nabarmenik sumatu. Erdi-mailako klaseak duen pisu handia da nafar gizartearen ezaugarri nagusienetako bat. Hori bi errealitateren emaitza da. Lehenik eta behin, ez da oso altua diru-sarrera jasoak dituztenen kopurua. Hau da, beste lurralde batzuekin alderatuta aberastasun handia duten familia gutxiago daude, finantza- edo industria-talde handien kontzentrazioak dituzten lurraldeekin alderatuz, batik bat. Bigarrenik, Estatuko gainerako leku gehienetan baino pobreziamaila baxuagoa dago. Bi ezaugarri horien ondorioz, pisu handiagoa dute soldata ertain eta ertain altuak dituztenek, eta oso gutxi handitu da Gini indizea krisi bitartean (desberdintasun hauek neurtzeko erabili ohi izan dena), 25,2 izatera iritsi delarik. Egoera hau, europar testuinguruarekin alderatuta ere oso ona da.

Alabaina, antzematen hasi da krisiaren eragina gizarteak birbanatzeko duen gaitasunean. Hau da, estutasunik gabeko klaseak bere mailari gogorki heltzen ari zaizkiola dirudi eta klase ahulenenganako elkartasunak behera egin duela. Ondorioz, muturreko pobrezia- mailak gora egin du krisiaren aldi honetan. Krisialdi aurretik, nafarren \% 7 bizi zen pobrezia erlatiboaren atalasetik behera. Portzentaje hori Estatukoaren bataz bestekotik oso behera dago, baldin eta Estatuko atalasea kontuan hartzen badugu (7.818 €). Baina krisiaren benetako eragina ulertu nahi badugu, eskualdeko baremo bat hartu behar da, lurralde berarekiko atalasetik abiatuta (11.522 €). Hau da, irabazi gutxi duen biztanleria aztertzeko, kontuan hartu behar dira gertukoek dituzten irabaziak (etxebizitzen prezioak, erosketa-saskia, kontsumo ohiturak, etab. haiekin partekatzen baitituzte). Baremo autonomiko hori erabiliz lortutako datuen arabera, dirusarrera baxuak ditu Nafarroako biztanleen \% 17ak, hau da, Estatuan ematen den antzeko proportzioa du. Beraz, orain artean Nafarroak izan ohi duen abantailazko egoera zehaztu beharko litzateke. Nafarroako aberastasuna kontutan hartu (bataz bestetik nabarmen gorago aurkezten dena) eta bertako atalaseak erabiltzean, antza handiagoa dagoela ikusten da gainerako lurraldeen gizarte-egiturekin. Estatuko beste lurralde batzuen antzekotasuna izatearen egoera hori, ongizate-sistemako funtsezko elementu batzuk partekatzearen ondorio moduan irakur daiteke; adibidez, sistema fiskala, gizarte- segurantza edo soldata-egitura berdinak izatearen ondorioz.

Beraz, orokorrean txikiagoa izan dela esan daiteke krisiaren eragina nafar gizartearentzako, eta bereziki krisiak sektore ahulenak astindu ditu, krisi aurretik bizi zituzten zailtasun egoerak nabarmenki okertu direlarik. Etxe horietako kideek kalitate gutxiagoko lana lortu zuten lan-merkatuan, etxebizitza eskuratzeko zailtasunak dituzte, ez dute familia-babes sendorik, eta ez dute jaso babes ekonomiko publikorik. Zentzu horretan oso argiak dira datuak: muturreko pobrezia 2010. urtean bikoiztu egin zen Nafarroan, \% 44ko portzentajera helduz. Garapen hori, Estatukoa baino askoz okerragoa da, eta kokatzen gaitu Europako datu okerrenak dituzten herrialdeen mailan, hau da, Grezia eta Kroaziaren pare. Gainera, etxe pobre horiek, are pobreagoak dira orain, izan ere, atalaserainoko distantzia \% 80 handitu baita azken urteotan. Ibilbide horrek arriskua agerian uzten du gizarte-haustura emateko, bai eta Nafarroak gizarte-babesa birbanatzeko duen gaitasunaren hondatzea gertatzeko ere.

Talde kaltetuenei erreparatuz gero, muturreko pobrezia-tasa bikoizten dute langabezian daudenek. Ondorio horiek tamaina handieneko familietan areagotzen dira (haietan muturreko pobrezia-tasa laukoizten da), adingabeak dituzten familietan (hirukoizten da) eta bakarrik bizi diren pertsonetan (bikoizten da). Azpimarratzekoa da muturreko pobrezia jasaten duten pertsonen artean langabetuak gutxiengoa direla. Aitzitik, lanean ari dira muturreko pobrezian bizi diren hamar pertsonetatik lau, hala ere, haien lanek bai diru-sarrera gutxi ematen dielako bai haien ezegonkortasun handia dela-eta (jardun murriztuak, aldi baterako lanak, etab.), ez dute haien egoera askorik hobetzen uzten. Lan-merkatuaren kasuan, errealitate horrek adierazpen argia dauka, hau da, ez dira etxe pobreenetara heldu langabezi babeserako mekanismoak; laguntza horiek, haatik, iritsi zaizkie pobre ez diren langabetuei. Bestalde, ezin ahantzi dezakegu Estatutik datozen errenten mende bizi den etxeetako errealitatea, pentsiodunak, esaterako. Horiei bereziki eragiten die, izan ere, lehenago bertako atalaseak erabiltzeko beharra aipatu den moduan, pertsona horiek jasotzen dituzten irabaziak ez datoz bat bizi diren errealitate sozial eta beharrekin. Ondorioz, Estatu-mailan diru-sarrera baxuak dituzten pertsona nagusien portzentajeak nabarmenki behera egin duen bitartean (krisi aurretik gertatu zen bezalaxe), gora egin du Nafarroan.

Azkenik, beste arloei helduta, eta adierazle ezberdinek erakutsitako datuen arabera, krisialdiak ez zituen kentze gehiegi ekarri 2010.urtea arte (etxea, hornitzeak, etab.). Hau azaltzeko, kontuan hartu behar dira, gizartean orokorrean eman den moduan, 
sektore ahulenen zorpetze-mailaren eta ordainketa ezaren emendioak. Hau da, kentzeek ez dute gora egin, zorpetze-mailak bai, ordea. Jokatzeko era horrek arrisku handia suposatzen du etxeen jarduteko duten esparru-aukera biziki urritzeko (gaur egun eta etorkizunean), bereziki irabazi gutxiagoko etxe eta kanpoko laguntzak izateko aukera gutxien dutenen etxeetako kasuan.

Jarduerari dagokionez, orokorrean, txikia izan da astindutako familien bolumena. Hori dela-eta, elkartasun-mekanismoak benetan posible izateaz gain, oso beharrezkoak dira. Zentzu honetan, gizartebabeserako mekanismoak berraztertu beharko lirateke, bereziki gutxieneko diru-sarrerak bermatzeko sistema, izan ere krisiak hauen eraginkortasun gabezia eta birbanatzeko dituen zailtasunak agerian utzi baititu.

Bestaldetik, lehen aipatutako pertsona ahulenen eta lan-merkatuaren arteko loturei helduta, birpentsatu behar dira aktibazio-politikak, arlo honen harmen eskasa ikusirik. Izaera aktiboagoko estrategietan ere eskas dira gainera. Era berean, beharrezkoa da Estatu-mailako diru-laguntza eta zerbitzu batzuek osatzea, Nafar lurraldeko etxeek dituzten benetako beharrei egokitu daitezen.

\section{Krisia eta bizi baldintzak: baztertutako biztanleriaren okertze nabaria}

Ikerketa honetan egin den bizi-kontakizunetan oinarritutako ikerketa kualitatiboari esker, aztertu ahal izan da 34 etxeetan krisiak izan duen eragina. Hasieran xumea nabaritzen den produktu hau ez da hutsala. Krisiaren ezaugarrietako bat izan da krisiaren garapena herritar guztiok jarraitu ahal izan dugula hedabideek etengabe kaleratu duten informazio eta adierazleen bidez. Ondorioz, gure eguneroko elkarrizketetan sartu ditugu Barne Produktu Gordina (BPG), defizitaren maila, arrisku-prima bezalako nozioak. Hala ere, informazio gutxi dago krisiak gizartean izan duen eraginaren inguruan. Esaterako, oso gutxi eztabaidatzen da langabeziak etxeetan eragiten duen moduaren inguruan. Hauxe da, hain zuzen, ulermena gaitzen duen metodologia honek eskainitakoa, langabeziaren ondorioak eta horrek bizi-baldintzen eraldaketan nola eragiten duen.

Bizi-kontakizunen bidez lortutako diskurtsoek erakusten dizkigute talde ahul eta baztertutakoen ezaugarriak, eguneroko arazoen larriagotzea, beharren areagotzea, ondorioei aurre egiteko zein ahalegin edota garatu izan dituzten ibilbideak. Bestalde, ikerketa-teknika horrek ahalbidetzen du etxebizitza-galtzeak, osasun fisiko eta buru-osasun arazoak, familia-mailan ematen diren gatazka- edo bizikidetza-arazoak edota isolatzeak bezalako baztertze-faktoreak antzematea. Ezin ahaztu daiteke, halaber, deskribatutako egoera konplexu horiek, krisia baino lehenagotik datozela maiz, eta etxe askok ezegonkortasun-egoeretan etengabe bizi izana dute ezaugarri ("krisialdian bizi izan naiz beti”). Etxe horietan, krisiak ekarri du aldez aurretiko arazoak areagotzea eta beste berri batzuk sortzea.

Etxe horietako egunerokotasunean sakontzean, hasieran antzematen da baztertze-egoeren ezaugarrietako bat, hau da, arazo ezberdinen metatzeak pairatzen dituzten familiengan sortarazten duen eragin gaiztoa. Aztertutako errealitateak oso ezberdinak izanagatik, denek dute komunean zailtasunen metatzea eta kanpoko laguntzarik gabe egoera horietatik ateratzeko ezintasuna. Adibidez, langabeziak eta horren ondorioz ematen den diru-sarrera ezak osasunean (fisiko eta buru-osasunean) eragindako hainbat gabezia ekartzen ditu (edo areagotzen ditu), eta aldi berean lanean hastea zailtzen dute.

Etxe horietan egunerokotasunean ematen diren etxekoen pasibotasunarekin maiz lotu izan diren zailtasunen areagotzeari aurre egiteko, martxan jarri izan dituzte beharrei erantzuteko taktika eta ekintzak. Abian jarritako estrategien artean, lehenik eta behin, bestelako lanak bilatzera zuzendutakoak daude, familiako irabaziak ziurtatu edo osatu aldera bideratuta. Bigarrenik, gizarte-babeserako mekanismo ezberdinetara jotzen dute, besteak beste, lan aholkularitza, laguntze sozial, etxebizitza-arloan laguntza, gutxieneko diru-sarrera prestazioak, etab. Hirugarrenik, lagun edo etxekoak ez diren beste senideen laguntza informalak eskuratzea da erabilitako beste bide bat. Kontsumo eta aisialdiko gastuen berrantolatzea, etorkinen etxeetan haien herrialdeetara diru gutxiago bidaltzea, etxebizitzari etekin handiagoa ateratzeko aukerak bilatzea edota krisiak gehien eragindakoen euren aurrezki edo jabetzak galtzea dira beste ekintza azpimarragarri batzuk. Nahiz eta bizi-baldintzen okertzea krisiak batez ere eragin, nahigabeko eraginak sortarazi ditzakete aipatutako estrategia horiek. Ondorio negatiboak ekar ditzakete baliabide ekonomikoen arloan jasandako gabeziei aurre egiteko hartutako neurri batzuek (harreman, osasun-arloan, etab.). Adibidez, diru-sarrerarik ez izatean martxan jartzen dira hainbat ekintza ezberdin, eta maiz dakarte gainzama mental, fisiko edota gatazkak bizikidetzan. Era berean, zailtasun-egoerei aurre egitekotan, aipatu dugun moduan, ondorio negatiboak ekar ditzakete pertsonen autonomia eta autoestimuan senideen artean laguntza eskatzeak. Adibide hauek erakusten digute errealitate ezegonkorrenek ezaugarri dituzten kiribil konplexuak.

Bizi-kontakizunen azterketen bidez egiaztatutako bazterketa-egoeretako beste bereizgarri bat da haien prozesu-izaera. Orokorrean, ikerketa-tresna hau erabiltzeak ahalbidetu digu diskurtsoa eta elkarrizketatutako pertsonen esperientziatik abiatuta bazterketa-egoeren izaera dinamikoa egiaztatzea. Nahiz eta langabeziak eta diru-sarrera gutxiago izateak familia gehienen egonkortasunean eragiten duen bereziki, gizarteratze edo ezegonkortasun-egoeran zeuden etxeen kopuru handi batean beheranzko ibilbidea jasan dute (maila ezberdinetan). Egoera horien eskutik zabaltzen dira ahultasun-espazio eta urritasunaren kiribil arriskutsuak, eta ezer gutxi egin dezakete haien atzaparretan ez erortzeko eguneroko estrategiek. 
Lehenago esan moduan, senitartekoen itzalak garrantzi itzela hartu du gizarte-arriskuak moteltze aldera. Oinarrizko harreman-egitura horrek egonkortasuna eta bermea eskaintzen die gizarte-babeserako mekanismoek asetzen eta erantzuten ez dituzten beharrei erantzuterakoan (ekonomikoak, bizilekukoak, etab.). Haatik, zalantzarik ez dago erakunde hori askotan gainezka egitekotan dela, eskari gehiegi izateagatik eta gero eta mugatuago den laguntza kudeatzeko zailtasunak direla medio. Erakunde honen garrantzia ikusirik, erraz antzeman daitezke baliabide hori ez duten pertsonek izaten dituzten zailtasunak. Hau da, faktore erabakigarria da familiababes eza baztertze-prozesuetan, eta, adibidez, langabezia eta diru-sarrera baxuen ondorioak ezagun edo senitartekoen laguntzaz moteldu ditzaketen etxeek, gutxitzea lortzen dute gaurko krisiaren eragin latzena.

Baina etxe horietan, gehienean, gizarte-zerbitzu eta gizarte-ekimeneko erakundeetara jotzen dute haien eguneroko bizi-iraupena bermatzeko. Gutxieneko diru-sarrera batzuei esker oinarrizko beharren asetzea, lehendabiziko urratsa da haien egoerari aurre egiteko. Dena dela, bizi-baldintzen konplexutasunak eta horien narriadurak kontuan hartuz, ezinbestekoa da etxe bakoitzari egokitutako diagnosi eta esku hartze plangintzak egitea: osasun-tratamenduak, etxebizitza ordaindu eta mantentzea, familiarteko bitartekaritza, eskolaratze jarraipen-prozesuen indartzea, lan-prestakuntzaren arloan aritzea, etab. Adibidez, oso baliabide eraginkorrak dira bazterketaegoeran dauden pertsona batzuentzako laneratzea eta prestakuntza esku hartze prozesuan. Bestalde, laguntza pertsonala eta laguntze soziala behar izaten dute langabezi egoeran denbora gutxi daramaten hainbat pertsonek. Behar zehatzei buruzko informazioaren hobetzea eskatzen da ekintza hauek pentsatu eta diseinatzerakoan, bai eta laguntze sozialaren bidez koordinatutako baliabideak erabiltzean ere.

Talde kaltetuenei dagokionez, eta txostenaren egitura guztian zehar egiaztatu daitekeen moduan, bizi-kontakizunek erakusten dute egoera zail askoren intentsitatea, bereziki emakumezkoak nagusi diren etxe, etorkin, ijito, gazte edo prestakuntza gutxiko pertsona helduen etxeetan. Diskurtsoek informazio estatistikoa izenpetzen dute, eta agerian uzten dute emakumezkoen okertze nabaria, lan-eskaintza gutxiagok eta aldez aurretik daudenen ezegonkortasunak eraginda (garbiketa, ostalaritza eta zaintzazerbitzuekin loturikoak, bereziki). Era berean, lanmerkatuan sartzeko desabantailak areagotzen dituzte etxeko lanen banaketan ematen diren desberdintasunek. Jatorriari erreparatuz, etorkinez osatutako etxeek bertakoz osaturikoak baino premia-egoera larriagoak pairatzen dituztela erakusten du, bi arrazoi nagusi tartean direlarik: lan-merkatuan sartzeko zailtasuna, eta laguntza-sare urriagoa izatea. Emakumezko etorkinak izan dira euren buruak ezegonkortasun- eta bazterketa-gune horietan sartzera behartuta ikusi dituztenak, batez ere zaintzen sektorean arituz. Nahiz eta paradoxikoki, eta egiaztatu daitekeen moduan, lan horiek familia askori eguneroko horni- gaiak bermatu dizkieten. Laneratzean ematen diren zailtasun horiek oso nabariak dira gazteengan. Haien enplegu-ezegonkortasunak eragozten die gutxienezko kotizazioak izatea, eta, beraz, at geratzen dira hainbat gizarte-babeserako tresnetatik. Ondorioz, atzeratu dira emantzipazio-prozesuak, eta familiek beregain hartu dituzte gain-kostuak, haien arteko gatazka-maila igotzen delarik kasu askotan. Hau da, garatutako estrategien izaera bikoitza erakusten du (positiboa eta negatiboa).

Azken finean, krisialditik ateratzeko talde-mailako neurri orokorrak hartzeaz gain, ezinbestekoa da babesik gabeko eta ahulenak diren etxeen beharrak bereziki aintzat hartzen dituzten laguntzak garatzea. Gizarte-baztertze prozesuen azkartasunak eta ekintza horien prebentzio-izaerak baztertutako biztanleriarentzako bereziki sortutako erreskate-plangintza bat zilegi egiten dute, krisialdiak gehien eragin dien taldeetako bat baita. Beraz, beheranzko ibilbideetan erortzear dauden pertsonak babestea beharrezkoa da, etxebizitza, gutxieneko diru-sarrera edo laneratzea bezalako kontuzko arloei bideratutako laguntzen bidez. Dena dela, hurrengo atalean egiaztatzen den moduan, murrizketa eta gizarte-gastua zalantzan jartzen den testuinguru instituzionalean, familia horiekin lan egiten duten zerbitzu eta gizarte-erakundeen eskariak modu deigarri batean gora egiteak eta zerbitzu horiek lanez gainezka egoteak, areagotzen ditu lehendik hasitako beheranzko ibilbideak.

\section{Krisia eta esku hartzea: gizarte- ekimeneko erakundeen eskarian izandako eragina}

Nafarroan, gizarte-baztertze egoeran dauden taldeekin lan egiten eskarmentu handia duten gizarte-ekimeneko erakunde asko egon izan ohi dira. Erakunde horien jarduna ulertzeko, ezinbestekoa da gizarte-zerbitzu publikoko sarea kontutan hartzea, izan ere azken honekiko nolabaiteko osagarritasuna eta bereizketa eskaini izan baitu. Talde bereziei arreta eskainiz (etxerik gabeko pertsonak, gutxiengo etnikoak, etorkinak, etab.) edo gizarte-ekintza arlo edo sektore berezitan arituz (etxebizitza, laneratzea, etab.). Lan egiteko era honek gizarte-politikari lotutako hainbat erabaki-guneetan nolabaiteko solaskidetza ematea ere ahalbidetzen zuen. Hala ere, krisiak emendio nabaria ekarri du erakunde horien eskarian, erakundeek erantzuteko duten ahalmena gainezka eginaraziz. Etxe askotan ematen diren zailtasun bortitzei sektore publikoek erantzuteko erakutsi duen ezintasunak, ezaugarritzen duen arintasuna medio, jende-kopuru altu bat erakunde horietara eskean joatera behartu du.

Krisia bera publikoki onartua izan eta urte eta erdi eskasean, talde ahulenei laguntza eskainitako Nafarroako hirugarren sektoreko erakundeek krisi aurretik baino $\% 27$ pertsona gehiagori laguntza eskaintzen zioten. Hiru urtetan, zenbateko hori \% 39 raino igo zen. Emendio honekin batera, nabariki aldatu zen 
laguntza eskatzen zuten pertsonen profila: biztanleria gazteagoa (17 eta 24 urte bitarteko gazteen kopurua hirukoiztu zen hiru urtetan eta 44 urtetik berakoak ziren 2010an lagundutako pertsonen $\%$ 70a), gizonekoen presentzia handiagotzea (2007an \% 39,5 izatetik 2010an \% 47 izatera pasa ziren) eta atzerritarren portzentaje altu batek osatzen zuten. Era berean, inolako diru-iturririk ez zuten pertsonen kopuruak, langabezi laguntza edo prestazioak jasotzen zituztenek, eta hein handi batean egin zuen gora oinarrizko errentari esker bizi ziren pertsonen zenbatekoak.

Eskarian izandako aldaketa horiek medio, erakunde horiek euren eguneroko ekintza berreraldatu behar izan zuten, arazo larrieneko kasuei lehentasuna emanez, adibidez, arropak ematea (hamar aldiz gehiago, hiru urtetan), egoitzetako harrera (zazpi aldiz gehiago), elikadura (sei aldiz gehiago) edo laguntza ekonomikoa (lau aldiz gehiago). Esku hartze hauek aurrera eramatean, alde batera utzi behar izan dituzte ordu arteko beste programa espezializatuago eta eraldatzaileago batzuek (prestakuntza, laguntze soziala, etab.). Erakunde horiek zituzten baliabide profesional eta ekonomikoak izanda (kasu batzuetan murrizketen ondorioz zinez gutxituak) biziki handitu da haiek laguntzeko eskaria, premia larridun eskaria izaki, gerturatzen da beste baliabide batzuk aurkitu ezinean. Ziurrenik oso erakunde gutxi dira horren asti gutxian bere lana horrenbeste gogortzeko gai, izan ere, Nafarroako gizarte-ekimeneko erakundeek krisi garaian lagundutako pertsonen kopurua biziki handitzeaz gain, aurrera eramandako esku hartze kopurua bikoizteko gai izan dira hiru urtetan.

Aritzeko modu honek makina bat barne-eztabaida sortarazi ditu erakunde horien baitan, krisialdi garaian eurek jokatu beharreko rola zela-eta. Izan ere, lehenago esan moduan, gutxieneko behar horien oinarrizko asistentzia ez baitzen ordu arte erakunde horiek euren gain hartutako funtzio nagusia. Aitzitik, haien lana gizarte-egoera konplexuak erantzutera bideratuak zeuden. Instituzio publikoek emandako erantzun kaskarrak, ordea, eskari sozial hori arintzen saiatzera eraman ditu erakunde hauek (irabazi asmorik gabeko erakundeek dituzten berezko mugekin), nahiz eta eskari hori erantzuteko gai ez direla eta beren gain hartu behar ez dutela pentsatu. Zentzu honetan, eztabaida-prozesu baten falta salatzen dute ageriko zailtasunak dituzten biztanle horiei eman beharreko erantzunaren inguruan. Gaur egun, nahiz eta erakunde hauek gizarte-eskari horren zati bat beregain hartzen ari diren, erakunde publikoek ez dituzte eztabaida eta hitzartzera gonbidatu, krisi aurretiko urteetan gonbidatu arren.

Talde ahulenen eskariak jasotzen dituzten heinean, krisiak talde hauengan izaten ari den eraginaren berri iritzi publikoari jakitera ematearen beharra sumatzen dute, nolabait. Lau haizeetara zabaldu nahi dute babes-sistemak ezin erantzun dabilen krisiaren eraginak zein diren jakiteko. Eta behin eta berriz azpimarratu nahi izan dute haien eguneroko esku hartzeak ez duela estali edo txikitu behar gizarteak bere osotasunean eta administrazioak bereziki, talde hauekiko duen erantzukizuna. Horregatik, erakundeek, BEGIZ berak bezalaxe, Oinarrizko Errentatik Gizarteratze-errentara pasatzean emandako araudialdaketek sortaraziko dituzten gizarte-ondorio larrien arriskuak azpimarratu nahi izan dituzte. Horrek, babes ekonomikorik gabeko 3.000 etxeetan eragingo duela jotzen dute. Azkenik, erakundeek beraiek azaltzen dute goraka doan eskari horri aurre egiteko dituzten mugak, are eta murrizketen ondorioz dituzten baliabide gero eta mugatuagoak kontutan hartuz. Erakunde horietan lan egiten duten profesionalen ahaleginaz eta nafarren elkartasunaz gain, erantzuna ez da aski eta gizarte-ekimeneko erakunde batzuen esku hartzeen jarraipena ere arriskuan jartzen duela esan dezakegu.

\section{Krisia eta proposamenak: Krisiak gizartean duen eraginei aurre egiten dien itun sozial bat}

Desberdintasun, Pobrezia eta Gizarte Bazterketa Nafarroan deritzon lehenengo txosten honen bidez, BEGIZ - Berdintasunerako eta Gizarte-Integraziorako Ikerketa Zentroak, lagundu nahi izan du krisiaren ondorioz areagotu diren pobrezia- eta baztertzeegoerei esfera politikoak (eta publikoak orokorrean) eskaintzen dion arreta eskasa gainditzen. Lehenago esan bezala, txostenean jasotako informazioak bultzatu nahi ditu azterketa jarrai eta sistematikoak, aldian behin Nafarroako desberdintasun sozialen eta biztanle ahulenen bizi-baldintzen berri izan dezagun, eta haien ezagutzan sakontzeko moduan egoteko. BEGIZek uste du, errealitate hauek jendaurrean jarri eta argitaratzeak, lehenik eta behin, egoera hauen inguruan kontzientziaziorako eta konpromiso publiko bat hartzeko bidea zabaldu dezakeela. Diagnosi ariketa hau programen eta hainbat gizarte-politiken desagertzeak ekar ditzaketen arriskuen inguruko erabakiak gidatu beharko luke. Zentzu honetan, aurre egin behar zaie gaur egun esparru ekonomikoari lotutako arreta guztia defizit publikoa murrizteko neurriak eskatzen dituzten ahotsei. Gastu soziala murriztu eta ekonomia piztera bideratutako neurriak, epe erdira arrakastatsuak balira ere, ez lirateke aski izanen arriskuan dagoen kohesio soziala bermatzeko. Hau da, gizarte-politika bereziak behar dira, behar handienak dituzten taldeei erantzunez, haustura soziala eragozteko.

BEGIZ osatzen dugun erakunde ezberdinek uste dugu, gaur egungo krisi testuinguruak talde konpromiso bat eskatzen duela, kohesio sozialaren maila babestu eta egoera zailenak errotik kentzeko. Itun hau gauzatzeko ezinbestekoa da ehun politikoaren parte hartzea, bai eta alde batera utzitako eztabaidari berriro ekitea ere, gizarte- eta lan-munduko eragileen inplikazioa ahalbidetuko bada, behintzat. Azken erakunde horiek ezinbestekoak dira, talde ahulenen egoera gertu-gertutik ezagutzen dute-eta. Norabide horretan, baztertutako taldeekin laneratze-prozesuetan lortutako esku hartze eskarmentuak, gizarte- 
ekintzako sektoreari ahalmena eman dio enplegu eta prestakuntza formula berriak garatzeko. Lankidetzan oinarrituta egonik, oso baliagarriak suertatzen ari dira gaur egungo testuinguru konplexuetan.

Krisialdiak kohesio soziala kolokan jartzen duen heinean, eskatzen du akordio sozial kolektibo bat lortzea. Hasitako gizarte-bazterketa prozesuak moteltzeko neurri-sorta eraginkorrak premiazkoak dira, eta krisiak gogorren kolpatutako etxeentzako erreskate-plan bat marraztu behar da. Plan horrek jaso beharko luke, besteak beste, etxe horientzako guztientzako gutxieneko diru-sarrera batzuen bermea, muturreko gabezia-errealitateak desagerra- razteko helburu dutelarik. Bigarrenik, prestakuntzaneurriak hartu beharko lirateke, zailtasun handienak dituzten pertsonen laneratzea erraztera bideratutakoak. Hirugarrenez, funtsezkoa da gizartearen babes-sistema ezberdinak inplikatzea (osasun, hezkuntza, etxebizitza, etab.) arazoak dituzten etxeen esku hartzeetan, arazo ezberdinei izaera prebentiboa duten erantzun koordinatuak emateko helburuari jarraikiz. Azkenik, gizarte-bazterketa egoeran aurkitzen diren pertsonen gizarteratzean funtsezkoak diren laguntze sozial eta lan espezializatuak mantentzeko, ezinbestekoa da gizarte-zerbitzuen sareak abiatutako esku hartzea eta gizarte-ekimeneko erakundeen ekintza mantentzea eta indartzea.

\section{Aipatutako bibliografia}

LAPARRA, M.; PÉREZ, B.; eta CORERA, C. (koord.) (2012): Primer informe sobre desigualdad, pobreza y exclusión social en Navarra. El impacto de la crisis 2007-2011, Iruña, Centro de Investigación para la Igualdad y la Integración Social [<http://www.redpobreza.org/es/documentosmainmenu-50/doc_download/406informe-impacto-crisis-2007-2011-ciparaiisnavarra-2012〉]. 